\title{
HUBUNGAN ANTARA KONFORMITAS DENGAN PERILAKU SEKSUAL PRANIKAH PADA REMAJA
}

\author{
Ayu Rahmaditha Apsari ${ }^{1}$,Santi Esterlita Purnamasari ${ }^{2}$ \\ ${ }^{12}$ Universitas Mercu Buana Yogyakarta \\ 12ayurahmaditha@gmail.com, ${ }^{2}$ santigautama@gmail.com
}

\begin{abstract}
Abstrak
Penelitian ini bertujuan untuk mengetahui hubungan antara konformitas dengan perilaku seksual pranikah pada remaja. Hipotesis yang diajukan dalam penelitian ini adalah ada hubungan positif antara konformitas dengan perilaku seksual pranikah pada remaja. Subjek penelitian ini adalah remaja tengah yang berada pada rentang usia 15-18 tahun sebanyak 60 subjek, 36 subjek laki-laki dan 24 subjek perempuan. Metode pengumpulan data dalam penelitian ini menggunakan skala konformitas dan skala perilaku seksual pranikah. Metode analisis data dalam penelitian ini menggunakan korelasi product moment dari Pearson. Hasil analisis menunjukkan bahwa ada hubungan positif yang signifikan antara konformitas dengan perilaku seksual pranikah pada remaja, yaitu rxy 0,748. Hal tersebut menunjukkan bahwa adanya hubungan positif antara konformitas dengan perilaku seksual pranikah pada remaja. Sehingga hipotesis pada penelitian ini dapat diterima. Semakin tinggi tingkat konformitas maka perilaku seksual pranikah pada remaja semakin tinggi, sebaliknya semakin rendah tingkat konformitas maka perilaku seksual ppranikah pada remaja semakin rendah.
\end{abstract}

Kata Kunci: konformitas, perilaku seksual pranikah, remaja

\section{THE CORRELATION BETWEEN CONFORMITY AND PRANICICAL SEXUAL BEHAVIOR IN ADOLESCENTS}

\author{
Ayu Rahmaditha Apsari ${ }^{1}$,Santi Esterlita Purnamasari ${ }^{2}$ \\ ${ }^{12}$ Universitas Mercu Buana Yogyakarta \\ 1ayurahmaditha@gmail.com, 22santigautama@gmail.com
}

\begin{abstract}
The aimed of this research was to reveal the relationship between conformity and pre-marital sexual behavior on teenagers. There was a positive relationship between conformity with pre-marital sexual behavior on teenagers. Subjects of this research was 60 teenagers, (36 male and 24 female around 1518 years old). Data was collected by conformity and pre-marital sexual behavior scale, then analyzed with product moment correlation by Pearson. The result showed that there was significant positive relationship between conformity and pre-marital sexual behavior on teenagers ( $r x y=0,748 ; p<0,01$ ). It means that the higher conformity score then the higher pre-marital sexual behavior as well.
\end{abstract}

Keywords: conformity, pre-marital sexual behavior, teenager

\section{PENDAHULUAN}

Masa remaja adalah masa transisi dari masa kanak-kanak ke masa dewasa. Masa remaja ditandai dengan perubahan- perubahan fisik pubertas dan emosional yang kompleks, dramatis serta penyesuaian sosial yang penting untuk menjadi dewasa (Sarwono, 2011).Kondisi demikian 
membuat remaja belum memiliki kematangan mental oleh karena masih mencari-cari identitas atau jati dirinya sehingga sangat rentan terhadap berbagai pengaruh dalam lingkungan pergaulan termasuk dalam perilaku seksualnya (Sarwono, 2011). Santrock, (2003) menyatakan bahwa remaja mulai berkembang dan melakukan perilaku seksual paling banyak pada rentang usia 15 hingga 18 tahun.

Berdasarkan pengertiannya perilaku seksual pranikah adalah kegiatan seksual yang melibatkan dua orang yang saling menyukai atau saling mencintai, yang dilakukan sebelum perkawinan (Indrijati, 2001). Lebih lanjut Sarwono (2013) menjelaskan Perilaku seksual pranikah adalah segala tingkah laku yang didorong oleh hasrat seksual, baik dengan lawan jenis maupun dengan sesama jenis tanpa adanya ikatan pernikahan yang sah. Adapun bentuk-bentuk perilaku seksual pranikah menurut Sarwono (2010), antara lain:

\section{a. Berpelukan}

Perilaku seksual berpelukan akan membuat jantung berdegup lebih cepat dan menimbulkan rangsangan seksual pada individu.

\section{b. Ciuman kering}

Perilaku seksual cium kering berupa sentuhan pipi dengan pipi dan pipi dengan bibir. c. Cium basah

Aktifitas cium basah berupa sentuhan bibir, dampak cium bibir dapat menimbulkan sensasi seksual yang kuat dan menimbulkan dorongan seksual sehingga tidak terkendali.

d. Meraba bagian tubuh yang sensitif

Merupakan kegiatan meraba atau memegang bagian tubuh yang sensitif seperti payudara, vagina dan penis.

e. Petting

Perilaku menggesek-gesekkan bagian tubuh yang sensitif, seperti menggesekkan tubuh dengan payudara pasangan hingga saling menempelkan dan menggesekkan alat kelamin. Dampaknya menimbulkan ketagihan.

f. Oral seksual

Oral seksual pada laki-laki adalah ketika seseorang mengunakan bibir, mulut dan lidahnya pada penis dan sekitarnya, sedangkan pada wanita melibatkan bagian disekitar vulva yaitu labia klitoris dan bagian dalam vagina.

\section{g. Intercourse atau bersenggama}

Merupakan aktifitas seksual dengan memasukkan alatkelamin laki-laki ke dalam alat kelamin perempuan.

Pernyataan Deputi Bidang Keluarga Berencana dan Kesehatan Reproduksi BkkbN Julianto Witjaksono yang dirilis pada tanggal 12 Agustus 2014 yang mengatakan jumlah remaja yang melakukan hubungan seks di luar nikah 
mengalami tren peningkatan. Berdasarkan catatan lembaganya, Julianto mengatakan 46 persen remaja indonesia berusia 15-19 tahun sudah berhubungan seks. Data Sensus Nasional bahkan menunjukkan 4851 persen perempuan hamil adalah remaja (BkkbN, 2014). Berdasarkan data statistik di atas, peneliti juga melakukan wawancara di daerah Umbulharjo terhadap delapan responden remaja yang berada pada usia 15 hingga 18 tahun yaitu (enam orang laki-laki dan dua orang perempuan) wawancara pada tanggal 23 dan 24 april 2015 hasilnya menunjukkan bahwa tujuh dari delapan responden menyatakan pernah melakukan perilaku seksual dengan pasangannya.

Pada tanggal 20 dan 22 November 2015 peneliti melakukan wawancara kembali di daerah Umbulharjo terhadap 4 responden remaja yang berada pada usia 15 hingga 18 tahun, yaitu 2 orang laki-laki dan 2 orang perempuan hasilnya menunjukkan bahwa keempat responden menyatakan pernah melakukan perilaku seksual dengan pasangannya. Perilaku seksual awal yang dilakukan ialah berpelukan, kemudian semakin meningkat menjadi mulai berani berciuman bibir, meraba bagian sensitif, oral seksual, hingga melakukan intercourse. Dua responden mengatakan belum pernah hingga melakukan intercourse sedangkan 2 responden lainnya pernah melakukan intercourse. Satu dari empat responden menjawab pertama melakukan perilaku seksual pranikah sejak menduduki bangku sekolah SMP dan 3 responden pertama kali melakukannya saat SMA.

Remaja yang menyalurkan dorongan seksualnya menjadi perilaku seksual seperti di atas, nantinya akan menimbulkan konflik pada dirinya yang akan berdampak pada psikologis, fisiologis, sosial, maupun fisiknya. Menurut Sarwono (2003), dampak yang akan ditimbulkan dari perilaku seksual pranikah diantaranya; perasaan marah, takut, cemas, depresi, rendah diri, merasa bersalah, berdosa, kehamilan yang tidak diinginkan sehingga melakukan aborsi, putus sekolah, dikucilkan, serta terkena PMS (Penyakit Menular Seksual). Meskipun demikian remaja cenderung untuk tetap berdalih sebagai pembenaran diri bahwa perilaku yang dilakukan, dalam hal ini perilaku seksual pranikah sudah biasa terjadi dan semua orang melakukan hal tersebut. Jadi perilaku yang dilakukan bukanlah suatu aib yang harus dihindari (Cohen, dalam Taufik dan Rachmah,2005).

Sesuai tugas perkembangannya, remaja diharapkan dapat mencapai perilaku sosial yang bertanggung jawab dan fokus pada sekolah (Hurlock, 2004). Masa remaja menekankan tugas pekembangan dalam bidang pendidikan, 
jadi diharapkan remaja dapat memiliki keterampilan intelektual dan konsep yang penting bagi kecakapan sosial, agar nantinya mereka mampu menunjukkan prestasi belajar remaja tersebut (Hurlock, 2004). Pada hakikatnya masa remaja seharusnya digunakan sebagai masa untuk menggali potensi-potensi yang ada dalam diri sebagai bekal menyongsong masa depan, namun fenomena yang ada memperlihatkan bahwa masa remaja juga digunakan untuk melakukan hal- hal tertentu, salah satunya dengan menyalurkan dorongan seksual.

Dorongan seksual yang dirasakan seseorang dapat memicu timbulnya perilaku seksual. Perilaku seksual yang dilakukan remaja bertentangan dengan norma yang berlaku di masyarakat. Perilaku seksual tersebut merupakan bukti adanya perilaku sosial dalam bidang hubungan heteroseksual yang seharusnya dapat dikembangkan dengan lebih positif mengikuti norma dan aturan yang berlaku (Faturrochman, 1992). Jadi seharusnya remaja melakukan tugas-tugas perkembangannya dengan baik sehingga mampu menunjukkan prestasi belajarnyadan tidak melakukan hal-hal yang negatif, salah satunya seperti perilaku seksual pranikah.

Menurut Pratiwi (2004) beberapa faktor-faktor perilaku seksual pranikah pada remaja adalah pengaruh biologis, pengaruh orang tua, pengaruh teman sebaya, akademik, pemahaman kehidupan sosial, pengalaman seksual, pengalaman dan penghayatan nilai-nilai agama, faktor kepribadian, dan pengetahuan mengenai kesehatan reproduksi. Dari faktor- faktor yang disebutkan di atas, penulis menitik beratkan pembahasan pada faktor teman sebaya, kemudian dari faktor tersebut dilihat sejauh mana konformitas terhadap teman sebaya dapat mempengaruhi perilaku seksual pranikah pada remaja. Adapun alasan pemilihan faktor tersebut adalah perilaku seksual pranikah pada remaja biasanya diawali dengan rasa ingin tahu untuk menambah pengalaman serta penasaran ingin mencoba karena pengalaman temannya yang sudah terlebih dahulu melakukan hubungan seksual pranikah, sehingga akhirnya perilaku tersebut menjadi hal yang biasa untuk dilakukan. Hurlock (2004) menyatakan konformitas dapat terjadi karena remaja lebih banyak berada di luar rumah bersama dengan teman-teman sebaya sebagai kelompok, maka dapatlah dimengerti bahwa pengaruh teman-teman sebaya pada sikap, pembicaraan, minat, penampilan, dan perilaku lebih besar daripada pengaruh keluarga. Bagi remaja pandangan terhadap dirinya merupakan hal yang paling penting (Santrock, 2007).

Pada masa remaja, remaja cenderung menyesuaikan dengan teman- 
teman sebayanya, konformitas terjadi apabila individu mengadopsi sikap atau perilaku orang lain karena merasa didesak oleh orang lain (baik desakan nyata atau hanya bayangan saja). Desakan untuk berperilaku sama pada kawan-kawan sebaya cenderung sangat kuat selama masa remaja, hal tersebut dilakukan karena dorongan untuk diterima dalam kelompok tinggi (Santrock, 2007). Rasa kebersamaan, persaudaraan, dan sikap konformitas remaja sangat tinggi dan mereka bisa keliru menggunakan perasaan tersebut untuk melakukan hal-hal yang sifatnya negatif (Talenta, 1996). Hal-hal yang bersifat negatif dalam hal ini, contohnya seperti perilaku merokok, membolos, minum-minuman keras, bahkan perilaku seksual pranikah. Bila remaja masuk ke dalam kelompok yang temantemannya sudah aktif melakukan perilaku seksual pranikah, maka tidak menutup kemungkinan remaja tersebut juga akan melakukan perilaku seksual pranikah karena remaja cenderung bersifat konformis (Mönks, dkk 1985). Definisi konformitas itu sendiri merupakan suatu jenis pengaruh sosial ketika seseorang mengubah sikap dan tingkah laku mereka agar sesuai norma sosial yang ada (Baron and Byrne, 2005). Taylor, dkk (2009) membagi aspek konformitas menjadi lima, yaitu; (a) peniruan, (b) penyesuaian, (c) kepercayaan, (d) kesepakatan, (e) ketaatan.
Menurut Mönks (2004) konformitas pada remaja terhadap kelompok teman sebaya terjadi karena dalam perkembangan sosialnya, remaja mulai memisahkan diri dari orangtua dan menuju ke arah temanteman sebaya.

Berdasarkan penjelasan di atas, Hipotesis yang diajukan dalam penelitian ini adalah adanya hubungan positif antara konformitas dengan perilaku seksual pranikah.

\section{METODE}

Variabel terikat dari penelitian ini adalah perilaku seksual pranikah dan variabel bebas dari penelitian ini adalah konformitas. Perilaku seksual pranikah adalah kegiatan seksual atau aktifitas fisik yang menggunakan tubuh untuk mengekspresikan perasaan seperti berpelukan, berciuman, sampai dengan bersenggama yang dilakukan dengan lawan jenis maupun sesama jenis disertai adanya dorongan hasrat seksual dengan tujuan untuk mendapatkan kepuasan atau kenikmatan seksual sebelum memiliki ikatan pernikahan yang sah baik secara hukum maupun agama.

Perilaku seksual pranikah diukur dengan Skala Perilaku Seksual Pranikah yang disusun peneliti berdasarkan teori dari Sarwono (2010), yaitu berpelukan, cium kering, cium basah, meraba bagian tubuh yang sensitif, oral seksual, petting, 
dan intercourse. Semakin tinggi skor yang diperoleh, semakin tinggi pula tingkat remaja melakukan perilaku seksual pranikah, sebaliknya semakin rendah skor yang diperoleh maka semakin rendah pula tingkat remaja melakukan perilaku seksual pranikah. Koefisien validitas Skala Perilaku Seksual Pranikah bergerak dari 0,4 sampai dengan 0,97 .

Konformitas

kecenderungan sosial yang dapat mempengaruhi perilaku individu untuk melakukan sesuatu atau menyamai perilakunya sesuai dengan norma yang ada. Konformitas merupakan kecenderungan seseorang untuk mengubah sikap dan tingkah laku, serta menyamakan perilaku agar sesuai dengan norma perilaku kelompoknya sehingga dapat diterima dan terhindar dari celaan.

Konformitas dari penelitian ini akan diungkap melalui Skala Konformitas yang disusun oleh peneliti yang terdiri dari aspek-aspek dalam konformitas menurut teori Taylor, dkk (2004), yaitu peniruan, penyesuaian, kepercayaan, kesepakatan, dan ketaatan. Semakin tinggi skor yang diperoleh maka cenderung semakin tinggi tingkat konformitas yang dimiliki subjek. Koefisien validitas Skala Konformitas bergerak dari 0,391 sampai dengan 0,695 dan menunjukkan koefisien reliabilitas alpha sebesar 0,958.
Subjek dalam penelitian ini remaja laki-laki dan perempuan berusia 15-18 tahun dan sedang berpacaran. Subjek pada penelitian ini berjumlah 60 orang. Pertimbangan memilih subjek usia 15-18 tahun dengan mengacu pendapat DeLamater dan MacCorquodale (dalam Santrock, 2003) yang menyatakan bahwa remaja mulai berkembang dan melakukan perilaku seksual paling banyak pada rentang usia 15 hingga 18 tahun dan Remaja yang sedang berpacaran lebih rentan melakukan kontak fisik berupa berciuman, berpelukan, bercumbu, hingga senggama (Hurlock, 1980). Menurut Prawiratirta (dalam Gunarsa 1986) pada masa pacaran, remaja akan mencapai suatu perasaan aman (feelings of security) dengan pasangannya. Feelings of security ini dapat menimbulkan suatu keintiman seksual pada diri mereka, sehingga sejumlah pengalaman yang terjadi pada masa berpacaran juga dapat memberikan perangsangan bagi remaja untuk mengadakan hubungan seksual pranikah. Menurut Setywan dan Nurhidayah (2008) remaja yang berpacaran mempunyai peluang yang cukup tinggi terhadap aktivitas/ perilaku seksual pranikah dan sebaliknya remaja yang tidak berpacaran akan semakin rendah mengarah pada perilaku/hubungan seksual pranikah.

Cara pengambilan subjek penelitian menggunakan teknik sampling insidental 
yaitu teknik penentuan sampel berdasarkan kebetulan, yaitu siapa saja yang secara kebetulan bertemu dengan peneliti dapat digunakan sebagai sampel, bila dipandang orang yang ditemui itu cocok sebagai sumber data (Sugiyono, 2009). Sebelum melakukan analisis data penelitian, terlebih dahulu peneliti melakukan uji normalitas dan uji linieritas untuk mengetahui sebaran data masing-masing variabel terdistribusi normal dan mengetahui linieritas hubungan antara variabel.

\section{HASIL DAN PEMBAHASAN}

Sebelum dilakukan analisis korelasi product moment untuk menguji hipotesis, maka ada beberapa asumsi yang harus dipenuhi terlebih dahulu. Asumsi untuk analisis korelasi product moment adalah data yang diukur mengikuti distribusi normal serta hubungan antar variabel bebas dan variable tergantung adalah linier.

Hasil uji normalitas sebaran data perilaku seksual pranikah menunjukkan nilai K-SZ sebesar 0,032 ( $p<0,05)$. Hal tersebut menunjukkan bahwa sebaran data perilaku seksual pranikah tidak normal namun tetap bisa dilakukan uji analisis korelasi karena subjek dalam penelitian ini menggunakan subjek lebih dari 30 yakni sebanyak 60 subjek. Hal ini didukung oleh Salim (1999) yang mengatakan semakin banyak subjek maka distribusi sampel mendekati distribusi normal meskipun untuk subjek yang tidak terdistribusi normal dengan jumlah subjek lebih dari 30. Untuk hasil uji normalitas sebaran data konformitas menunjukkan nilai K-SZ sebesar 0,200 ( $\mathrm{p}>0,05)$ yang artinya sebaran data konformitas terdistribusi normal. Hasil uji linieritas variabel konformitas dan perilaku seksual pranikah menunjukkan nilai koefisien linier $\mathrm{F}$ sebesar 133.940 dengan taraf signifikansi sebesar $p=0,000(p<0,05)$. Berdasarkan analisis tersebut dapat diambil kesimpulan bahwa ada hubungan yang linier antara konformitas dengan perilaku seksual pranikah.

Berdasarkan hasil analisis product moment diperoleh koefisien korelasi antara konformitas dengan perilaku seksual pranikah rxysebesar 0,748 dengan taraf signifikansi $0,000(\mathrm{p}<0,01)$ dan diperoleh koefisien determinasi ( $R$ Squared) antara konformitas dengan perilaku seksual pranikah $\mathrm{R}^{2}$ sebesar 0,560 yang berarti bahwa konformitas memberikan sumbangan efektif sebesar $56 \%$ terhadap perilaku seksual pranikah remaja sedangkan $44 \%$ dipengaruhi faktor-faktor lain. Hal tersebut menunjukkan bahwa ada hubungan positif antara konformitas dengan perilaku seksual pranikah, yang berarti semakin tinggi konformitas maka cenderung semakin tinggi perilaku seksual pranikah, begitupun sebaliknya semakin 
rendah konformitas maka cenderung semakin rendah perilaku seksual pranikah. Dengan demikian hipotesis yang diajukan dalam penelitian ini diterima.

Adanya hubungan antara konformitas dengan perilaku seksual pranikah pada remaja berarti bahwa konformitas memberikan sumbangan terhadap perilaku seksual pranikah pada remaja. Hal tersebut terjadi karena dalam perkembangan sosialnya, remaja mulai memisahkan diri dari orangtua dan menuju ke arah teman-teman sebaya (Monks, 2004). Peran konformitas dalam pergaulan remaja sangatlah tinggi sehingga dapat mempengaruhi remaja dalam berperilaku, salah satunya perilaku seksual pranikah.

Perilaku seksual pranikah sudah menjadi bagian yang umum dalam dalam hubungan remaja. Keterlibatan dirinya dengan kelompok dan ketertarikan terhadap identifikasi kelompok meningkat. Remaja menjadikan teman sebaya sebagai penasehat terhadap segala sesuatu tindakan dan tempat bercerita yang dapat mengerti keadaan dirinya. Simpati antar teman sebaya menjadi sangat tinggi sehingga apapun yang teman kelompoknya lakukan, dilakukan juga oleh yang lain. Hal tersebutlah yang membuat konformitas pada masa remaja menjadi tinggi

Remaja akan merasa senang apabila diterima dalam kelompoknya atau sebaliknya akan tertekan dan cemas apabila dikucilkan atau diremehkan (Santrock, 2007). Pada masa remaja, remaja memperoleh pengetahuan sosial yang lebih banyak, dan perbedaan variasi antar individu dalam hal seberapa baik pengetahuannya dalam mencari teman, dalam usaha membuat teman sebayanya lebih menyukainya (Santrock, 2003). Karateristik pada masa remaja menjadi bagian dalam sebuah kelompok adalah suatu hal yang penting (Santrock, 2007). Berada dalam lingkungan peer dapat membuat perilaku yang dilakukan remaja satu mempengaruhi remaja lainnya agar diterima dalam kelompok. Hubungan relasi yang baik di antara kawan-kawan sebaya dibutuhkan bagi perkembangan sosial yang normal di masa remaja, karena karateristik pada masa remaja menjadi bagian dalam sebuah kelompok adalah suatu hal yang penting (Santrock, 2007). Di dalam kelompok teman sebaya, remaja sangat bergantung kepada teman sebaya sebagai sumber kesenangannya sehingga keterikatan dengan teman sebaya menjadi sangat kuat, kemudian akan diikuti dengan adanya perilaku konformitas, dimana remaja akan berusaha untuk menyesuaikan dan menyatu dengan kelompok agar remaja dapat diterima oleh kelompoknya (Soetjiningsih, 2008). Konformitas yang terjadi pada kelompok teman sebaya tersebut akan memberi peluang yang lebih besar pada remaja dalam berperilaku, 
apabila perilaku kelompok teman sebayanya aktif melakukan perilaku seksual pranikah maka besar juga peluang remaja tersebut mengikuti perilaku kelompoknya tersebut untuk melakukan perilaku seksual pranikah.

Dalam Susilowati (2011) disebutkan bahwa teman sebaya berfungsi sebagai penyedia informasi mengenai dunia di luar keluarga. Dari kelompok teman sebaya, remaja menerima suatu umpan balik tentang potensi yang ia miliki, dan belajar mengenai apakah perilakunya lebih baik, sama baiknya, atau bahkan lebih buruk dari remaja lainnya. Manusia merupakan makhluk peniru, sehingga banyak perilaku manusia terbentuk melalui proses peniruan (Rakhmat, 2009). Dalam hal ini, perilaku seksual pranikah dapat terjadi jika remaja satu sudah pernah melakukan perilaku seksual pranikah, maka remaja yang lain pun akan mencoba meniru perilaku seksual pranikah yang dilakukan remaja satunya. Remaja melakukan apa yang dilakukan anggota kelompok demi memperoleh persetujuan atau menghindari celaan kelompok, tanpa memperdulikan perasaannya sendiri (Hurlock, 1996). Tekanan itu bisa saja berupa paksaan yang harus disepakati dan ditaati, seperti merokok, menggunakan narkoba, bahkan melakukan hubungan seksual pranikah (Susanto, 2006). Sarwono (2003) menjelaskan karena kuatnya ikatan emosi dan konformitas kelompok pada remaja, maka biasanya hal ini sering dianggap juga sebagai faktor yang menyebabkan munculnya tingkah laku remaja yang buruk. Apabila lingkungan peer remaja tersebut mendukung untuk dilakukan seksual pranikah, serta konformitas remaja yang juga tinggi pada peer-nya, maka remaja tersebut sangat berpeluang untuk melakukan seksual pranikah.

Berdasarkan hasil kategorisasi skor perilaku pranikah menunjukkan bahwa terdapat 19 remaja $(31,67 \%)$ memiliki perilaku seksual pranikah yang tinggi, 21 remaja memiliki perilaku seksual pranikah yang sedang (35\%), dan 20 remaja $(33,33 \%)$ memiliki perilaku seksual yang rendah. Sehingga sebagian besar subyek memiliki perilaku seksual pranikah dengan intensitas yang sedang. Dari hasil penelitian tersebut diketahui bahwaterdapat 14 remaja $(23,33 \%)$ memiliki tingkat konformitas yang tinggi, 27 remaja (45\%) memiliki tingkat konformitas yang sedang, dan 19 remaja $(31,67 \%)$ memiliki tingkat konformitas yang rendah. Sehingga sebagian besar subjek dalam penelitian ini memiliki tingkat konformitas yang sedang. Artinya subjek dalam penelitian ini memiliki tingkat konformitas yang sedang sehingga perilaku seksual pranikah yang dilakukan remaja pun cenderung dalam kategori sedang. 
Remaja yang melakukan perilaku seksual pranikah dapat termotivasi oleh pengaruh kelompok untuk melakukan konformitas dengan mengikuti normanorma yang telah dianutnya. Di dalam kelompok, remaja sangat bergantung kepada teman sebaya sebagai sumber kesenangannya sehingga keterikatan dengan teman sebaya menjadi sangat kuat, kemudian akan diikuti dengan adanya perilaku konformitas, dimana remaja akan berusaha untuk menyesuaikan dan menyatu dengan kelompok agar remaja dapat di terima oleh kelompoknya (Soetjiningsih, 2008).

\section{KESIMPULAN}

Berdasarkan hasil penelitian dan pembahasan dapat ditarik kesimpulan bahwa ada hubungan positif antara konformitas dengan perilaku seksual pranikah pada remaja dengan koefisien sebesar rxy0,748 dengan taraf signifikansi $0,000(\mathrm{p}<0,01)$ dan diperoleh koefisien determinasi (R Squared) antara konformitas dengan perilaku seksual pranikah $r^{2}$ sebesar 0,560 yang berarti bahwa konformitas memberikan sumbangan efektif sebesar $56 \%$ terhadap perilaku seksual pranikah remaja sedangkan $44 \%$ dipengaruhi faktor-faktor lain.. Hal ini berarti semakin tinggi tingkat konformitas maka semakin tinggi perilaku seksual pranikah yang dilakukan remaja.
Sebaliknya semakin rendah tingkat konformitas maka semakin rendah perilaku seksual pranikah pada remaja. Dari hasil kategorisasi dapat disimpulkan bahwa sebagian besar remaja memiliki perilaku seksual pranikah dengan intensitas yang sedang dan tingkat konformitas yang sedang.

Berdasarkan kesimpulan yang telah dikemukakan peneliti maka dapat diajukan saran sebagai berikut:

1. Bagi remaja

Hasil penelitian ini menunjukkan bahwa perilaku seksual pranikah pada subyek berada dalam kategori sedang, namun hal ini tetap menandakan adanya perilaku seksual pranikah pada subyek ketika berada di lingkungan teman sebaya ataulingkungan di luar keluarganya. Oleh karena itu disarankan kepada remaja agar lebih berhati-hati dan selektif dalam bergaul dan memilih kelompok teman, agar para remaja tidak terpengaruh dan terjerumus ke dalam pergaulan yang menyimpang, sehingga perilaku seksual pranikah pada remaja dapat dikurangi.

2. Bagi peneliti selanjutnya

Penelitian ini menunjukkan adanya pengaruh konformitas terhadap perilaku seksual pranikah pada remaja. Peneliti selanjutnya disarankan mengkaji variabel lain 
atau faktor-faktor lain yang menyebabkan remaja melakukan perilaku seksual pranikah, seperti faktor libido seksual, penundaan usia perkawinan, norma agama, sikap orangtua yang masih mentabukan seks, dan pergaulan yang semakin bebas, pemahaman diri, faktor kepribadian, dan pengetahuan mengenai kesehatan reproduksi. Adapun kelemahan dalam penelitian ini yaitu hanya mengungkap seberapa dalam perilaku seksual pranikah yang remaja pernah lakukan tanpa memperhatikan seberapa sering (frekuensi) yang remaja tersebut lakukan dan kurang memperhatikan kualitas dari perilaku seksual pranikah yang dilakukan remaja. Jadi diharapkan peneliti selanjutnya yang tertarik dengan tema yang sama dapat lebih memperhatikan frekuensi dan kualitas dari perilaku seksual pranikah yang dilakukan remaja. Selain itu untuk peneliti yang tertarik dengan tema perilaku seksual pranikah diharapkan lebih dapat melihat perilaku seksual pranikah pada subjek yang berorientasi homoseksual untuk melihat pandangan secara lebih luas.

\section{DAFTAR PUSTAKA}

Badan Pusat Statistik. (2012). Survei Demografi dan Kesehatan Indonesia Kesehatan Reproduksi Remaja (SDKIRR). Jakarta: Badan Pusat Statistik.

Faturochman. (1992). Sikap dan Perilaku Seksual Remaja di Bali. Jurnal Psikologi.1 (1); 12-17

Gunarsa, S.D.(1986). Psikologi Remaja. Jakarta: BPK Gunung Mulia.

Hurlock, E.B. (1980). Psikologi Perkembangan : Suatu Pendekatan Sepanjang Rentang Kehidupan. Jakarta : Erlangga.

Hurlock, E.B. (1996). Psikologi Perkembangan : Suatu Kehidupan Sepanjang Rentang Kehidupan. Jakarta: Erlangga.

Hurlock, E.B.(2004). Psikologi Perkembangan Suatu Pendekatan Sepanjang Rentang Kehidupan (edisi kelima). Jakarta: Erlangga.

Indrijati, H. (2001). Hubungan Antara Kualitas Komunikasi Remaja Dan Orang Tua Dan Sikap Remaja Terhadap Hubungan Seksual Pranikah. Jurnal Psikologi Kepribadian dan Sosial: 3 (2); 93102.

Mönks, F. J. Knoers, A.M.P. \& Haditomo, S.R. (1985). Psikologi Perkembangan Pengantar dalam Berbagai Bagiannya. Yogyakarta: Penerbit Fakultas Psikologi UGM.

Mönks, F.J. Knoers, A.M.P. \& Haditomo, S.R. (2004). Psikologi Perkembangan: Pengantar Dalam Berbagai Bagiannya. Yogyakarta: Gadjah Mada University Press. 
Pratiwi, A.D. (2004). Pendidikan Seks untuk Remaja.Yogyakarta: Tugu Publisher.

Rakhmat, J. (2009). Metode Penelitian Komunikasi. Bandung: PT. Remaja Rosadakarya.

Setiawan, R. \& Nurhidayah, S.(2008). Pengaruh Pacaran Terhadap Perilaku Seks Pranikah. Soul, 1 (2); 17-38.

Santrock, J. W. (2003). Adolescence: Perkembangan Remaja. Jakarta: Erlangga.

Santrock, J. W. (2007). Perkembangan Anak (Edisi ke-11). Jakarta: Erlangga.

Sarwono, S.W. (2003). Psikologi Remaja. Jakarta: PT Raja Grafindo Persada.

Sarwono, S.W. (2010). Psikologi Remaja. Jakarta: PT Raja Grafindo Persada.

Sarwono, S.W. (2011). Psikologi Remaja. Jakarta: PT Raja Grafindo Persada.

Sarwono, S.W. (2013). Psikologi Remaja. Jakarta: PT Raja Grafindo Persada.

Soetjiningsih. (2008). Perkembangan Anak dan Permasalahannya. Jakarta: Sagung Seto.
Sugiyono. (2009). Metode Penelitian Kuantitatif Kualitatif Dan $R \& D$. Bandung: Alfabeta.

Susilowati, K. (2011). Hubungan Antara Konformitas Teman Sebaya Dan Konsep Diri Dengan Kemandirian Pada Remaja Panti Asuhan Muhammadiyah Karanganyar. Skripsi (tidak diterbitkan).Surakarta: Program Studi Psikologi Fakultas Kedoteran Universitas Sebelas Maret Surakarta.

Susanto, H. (2006). Mengembangkan kemampuan Self Regulasi untuk Meningkatkan Keberhasilan Akademik Mahasiswa. Jurnal Pendidikan Penabur. Vol 5 (7); 6471.

Talenta, S. (1996). Biarkan Kami Bicara (Tentang Sekolah dan Cita-Cita). Yogyakarta: Pustaka Remaja Kanisius.

Taylor, E. Shelley, Peplau, L.A, \& Sears, D.O. (2009). Psikologi Sosial Edisi Kedua Belas. Jakarta: Kencana.

Taufik \& Rachmah, N. (2005). Seksualitas Remaja: Perbedaan Seksualitas antara Remaja yang Tidak Melakukan Hubungan Seksual dan Remaja yang Melakukan Hubungan Seksual.Jurnal Penelitian Humaniora, 6 (2); 115-129. 